\title{
STUDY OF VIRAL MARKERS (HIV, HBV, HCV) IN A TERTIARY CARE HOSPITAL
}

Samatha $\mathrm{P}^{1}$

\section{HOW TO CITE THIS ARTICLE:}

Samatha P. "Study of Viral Markers (HIV, HBV, HCV) in a Tertiary Care Hospital". Journal of Evolution of Medical and Dental Sciences 2015; Vol. 4, Issue 85, October 22; Page: 14787-14791, DOI: 10.14260/jemds/2015/2104

ABSTRACT: BACKGROUND: Viral infections are global health problems, affecting millions. Studies show wide variations in the prevalence patterns of the Human Immuno deficiency, Hepatitis B and Hepatitis C Virus infections. Prevalence of these infections may vary not only from country to country but also in different regions of the same country. The present study was designed to find out the seroprevalence of HBV, HCV, and HIV infections in patients attending a tertiary care hospital. METHODS: A prospective study was conducted for a period of one year from April 2014 to March 2015. A total of 4276 patients were screened for Hepatitis B surface Antigen (HBsAg), anti HCV antibodies and anti HIV antibodies. Patients with symptoms or signs of these viral infections and the patients for routine pre-surgical evaluation, referred by the clinicians were included in the study. Age, sex and serological result data was analysed for these patients. The results were analysed by Chi- square statistics. RESULTS: The sero-prevalence of HBsAg was 2.5\%, anti HCV antibodies was $0.63 \%$, anti HIV antibodies was $1.73 \%$ whereas, co-infection of HBsAg with HIV was seen in only three patients. CONCLUSION: In the present study, the sero-prevalence of Hepatitis B Virus (HBV) was higher than HIV and HCV infections. As these viral infections are dangerous and cause morbidity and mortality, population based awareness \& screening programmes are recommended to limit the further spread.

KEYWORDS: Hepatitis B Virus (HBV), Hepatitis C Virus (HCV), Human immunodeficiency virus (HIV), Co-infection.

INTRODUCTION: Infections with different types of microorganisms like bacteria, virus, fungi, and parasites are common in Indian scenario among which infection with Hepatitis B Virus (HBV), Hepatitis C Virus (HCV) and Human Immunodeficiency Virus (HIV) are common. In the last two decades, co-infection of three most important viral agents viz. Hepatitis B virus (HBV), Hepatitis C virus (HCV) and Human immunodeficiency virus (HIV), has emerged as a leading cause of morbidity due to associated liver disease. ${ }^{1,2}$ The fact that Hepatitis virus and the HIV share similar routes of transmission contributes to co-infection. ${ }^{1,3}$ Sexual activity and/or injection drug use are the most common routes of transmission of the hepatitis B virus among those also infected with HIV. Transmission of HCV is generally through blood transfusion and injection drug use. HCV can be transmitted sexually, but that such transmission is generally inefficient.

The likelihood of HCV infection increases with the number of lifetime sexual partners. Health care workers who have exposure to blood are at risk of infection with HCV. Conditions associated with hepatitis $\mathrm{B}$ and $\mathrm{C}$ are currently among the leading causes of hospital admission in HIV-infected population. ${ }^{4}$ In co-infection, the presence of one virus impacts the natural history of the other virus. HIV accelerates the natural course of HBV and HCV infections and facilitates faster progression of liver disease to cirrhosis and hepatocellular carcinoma. ${ }^{4}$ Understanding HBV and HCV co-infection with HIV is helpful in Asian countries due to high prevalence of HBV and HCV.4,5 Sero-surveys are one of the primary methods which can be used to determine the prevalence of HBV and HCV, and help in 


\section{ORIGINAL ARTICLE}

the creation of long-term strategies to improve the public health. ${ }^{6}$ Proper selection of the quality screening tests, adequate control measures and effective biomedical waste inactivation procedures can ensure the reduction of the risk of acquiring transfusion transmitted infections. ${ }^{6}$

MATERIALS AND METHODS: Study of prevalence is essential to understand \& assess the magnitude of disease in society, to plan better prevention strategies. The present study was undertaken with the objective to assess the presence of HBV, HCV, and HIV infections in patients attending a tertiary care hospital in Guntur.

STUDY DESIGN: This study was carried out in the Serology Section of the Department of Microbiology, after an approval from the institutional ethics committee. HIV antibody detection was performed after pretest counseling and informed consent of the patient. Reactive results of HIV antibody testing were disclosed only after post-test counseling.

PATIENTS \& PERIOD OF STUDY: Patients who registered as outpatients or admitted as inpatients of a teaching medical college hospital, who are advised to undergo HIV and HCV antibody testing and hepatitis B screening were included in the study. The study was done over a period of 12 months from April 2014 to March 2015 on a group of 4276 patients.

SPECIMEN COLLECTION: Five milliliters of venous blood sample was collected from all patients for testing of HBsAg, HCV, and HIV antibodies. The blood was allowed to clot for 45 minutes at room temperature and the serum was separated after centrifugation at a low speed of $2-4 \times 10^{3}$ r.p.m. The serum sample was then subjected to tests.

SEROLOGY: Serum collected was tested by using standard recommended procedure. HBsAg was determined by using a rapid card method Hepacard (Biomed industries), antibodies to HCV by HCV Tridot (Biomed industries), and antibodies to HIV by HIV Tridot (Biomed industries). All the tests were performed in accordance with the manufacturer's instructions with adequate controls. Samples testing reactive were further rechecked by Enzyme linked immunosorbent assay (ELISA).

EXCLUSION CRITERIA: The repeat visitors were excluded.

STATISTICAL ANALYSIS: SPSS software version 16 was used for the statistical analysis. Chi-square test at significance level of 0.05 was used for testing the association between demographic parameters and presence of various infections and co-infections.

RESULTS: Out of 4276 patients, a total of 211(4.93\%) were sero-positive for HBV, HCV, and HIV cases. Hepatitis B surface antigen was tested positive in 107 cases (2.50\%) among which 74 were Males and 33 were females. Hepatitis C Virus was positive in $27(0.63 \%)$ of which 17 were males and 10 were females. Out of 17 males, twelve were above the age of 50yrs. HIV1 was reactive in 74(1.73\%) of which 45 were males and 29 were females (Table 1). None of the patients were reactive for HIV2. Coinfection in the form of HBV \& HIV was seen in three male patients. None of the patient's samples were positive for co-infections like HBV \& HCV and HCV \& HIV. Among the total seropositive cases, majority $(n=136)$ were in the age group of 20 to 50 years (Table 2$)$. 


\section{ORIGINAL ARTICLE}

\begin{tabular}{|c|c|c|c|}
\hline Infections & Males n=2237 & Females n=2039 & Total n=4276 \\
\hline HBV & 74 & 33 & 107 \\
\hline HCV & 17 & 10 & 27 \\
\hline HIV & 45 & 29 & 74 \\
\hline $\begin{array}{l}\text { Co infection } \\
\text { (HBV+HIV) }\end{array}$ & 03 & nil & 03 \\
\hline \multicolumn{2}{|c|}{ Table 1: Seropositivity of HBV, HCV, HIV \& Co-Infection } \\
\hline
\end{tabular}

\begin{tabular}{|c|c|c|c|c|}
\hline Age & HBV $\mathbf{n = 1 0 7}$ & HCV $\mathbf{n = 2 7}$ & HIV $\mathbf{n = 7 4}$ & Co infection \\
\hline$<20$ years & 03 & 00 & 00 & 00 \\
\hline 21-50 years & 75 & 10 & 48 & 03 \\
\hline$>50$ years & 29 & 17 & 26 & 00 \\
\hline \multicolumn{5}{|c|}{ Table 2: Age relation to viral infections } \\
\hline
\end{tabular}

DISCUSSION: A history of multiple sex partners, irregular condom use, and co-infection with other sexually transmitted infections constitutes the potential risk factors of HIV infection. The Hepatitis B and $\mathrm{C}$ viral infections are highly prevalent among HIV-infected persons, generally as a result of the shared transmission routes, namely sexual, parenteral and perinatal. ${ }^{1}$ The prevalence of these viral infections varies from country to country and depends upon a complex mixture of behavioural, environmental, and host factors.

In general, it is lowest in areas with high standards of living like Australia, North America, and North Europe and highest in areas with low socioeconomic status like China, Southeast Asia, South America, and Africa. ${ }^{7}$ Analysis of our results revealed that in a total of 4276 individuals screened, 211(4.93\%) were positive for one of the HIV, HBV or HCV infections.

According to World Health Organization (WHO), India has been placed into the intermediate Zone of prevalence for Hepatitis B (2-7\%). In a study conducted in a hospital-based population at Kathmandu Medical College Hospital, Nepal, the prevalence rate of Hepatitis B surface antigen was found to be $2.5 \%{ }^{8}$ which coincided with the present study $(2.5 \%)$. In India a low prevalence of $1.0 \%$ has been reported by Hussain et al. ${ }^{9}$ Seroprevalence of HCV infection varied among hospital based populations in different regions of India. More Seroprevalence rates $(4.8 \%)$ were reported from Pondicherry ${ }^{10}$ followed by Jodhpur $(2.46 \%) .{ }^{11}$ followed by Cuttack $(1.57 \%) .{ }^{12} \mathrm{HCV}$ infection was present in only 27 patients $(0.63 \%)$ in the present study.

Presently, India is a home for 2.27 million HIV positive cases (UN AIDS 2010). Andhra Pradesh is among the high prevalence states next to Manipur (NACO onlineorg. annual report 2010-11). Our study shows the seroprevalence for anti-HIV antibodies to be $1.73 \%$. People with co-infections have high viral loads. Risk of mortality and morbidity increases due to shared transmission pathways and synergistic effects of both viruses. In the present study, the prevalence of co-infection was found to be $0.07 \%$. Analysis of our results showed that age and sex influenced the prevalence rates of HIV, HBV and HCV infections like that of other studies (Figure 1\&2).9,13,14 The higher prevalence of these viral infections in the age group of 21-50 is attributable to the higher sexual activity of this age group. (Figure 2). 


\section{ORIGINAL ARTICLE}

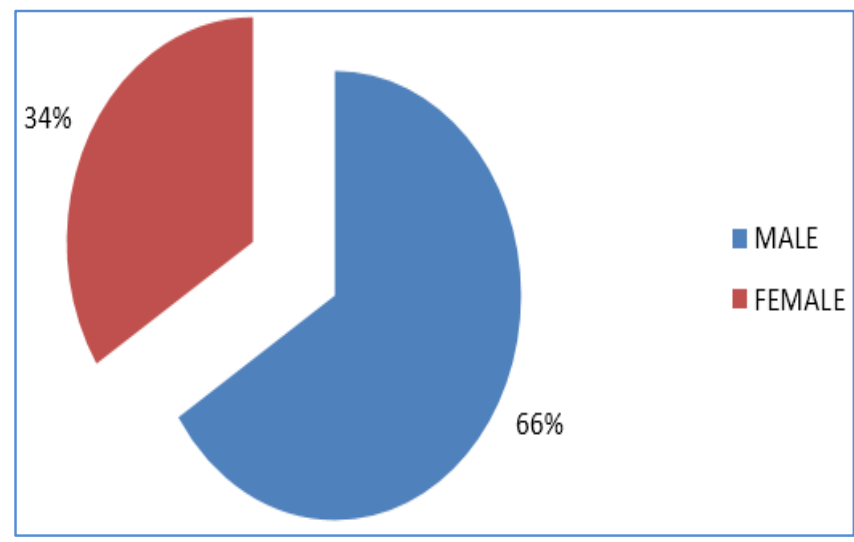

Fig. 1: HIV, HBV, HCV infections in Males and Females

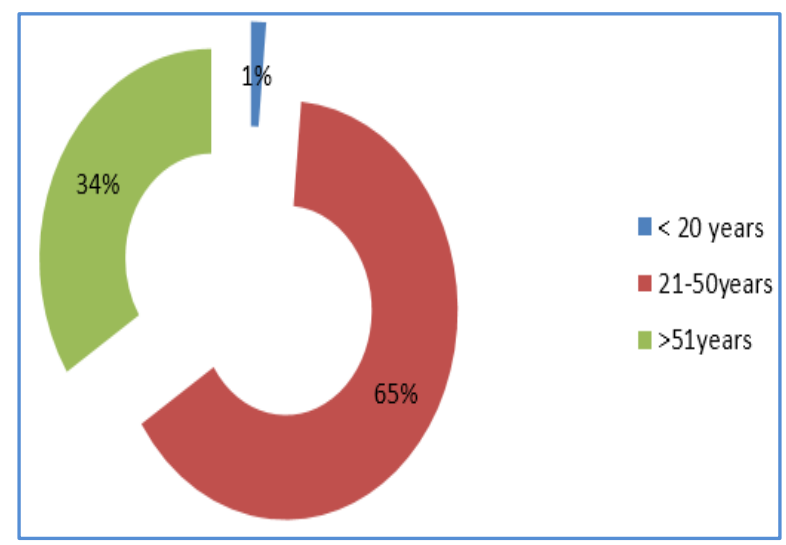

Fig. 2: Relationship between age and HIV, $\mathrm{HBV}$, and $\mathrm{HCV}$ infections

\section{CONCLUSIONS:}

- HBV infection was more prevalent followed by HIV \& HCV.

- HBV, HIV infections were more in 21-50 yrs. age group.

- HCV infection was more prevalent after 50 years.

- Males were affected more than females.

- In both sexes, 21-50 years age group people suffered maximum.

\section{SUGGESTIONS:}

1. Active governmental, educational \& media campaign about the risks of infection, routes of transmission \& methods of protection may help to bring down prevalence rates.

2. Integration of Hepatitis B \& C Screening programmes with Integrated Confidential Testing Centre.

3. Premarital screening programmes for all types of contracting dangerous diseases must be made mandatory by central and state governments to prevent spread of infections.

4. The Hepatitis viral markers should be tested in the HIV positive individuals.

5. HBV vaccination should be given as per schedule for prevention.

"EARLY DETECTION-EARLY TREATMENT": campaign may help to limit the transmission of these viral infections. In the absence of an effective treatment for these three viral infections, prevention remains the key solution for the patient protection. Though separate recommendations for HIV$\mathrm{HBV} / \mathrm{HCV}$ co-infection do not exist, screening remains important in this population as Hepato-cellular carcinoma incidence has been increasing among HIV-infected individuals. The estimation of the Seroprevalence of $\mathrm{HIV} / \mathrm{HBV} / \mathrm{HCV}$ co infection is essential information for effective implementation of control programs.

\section{REFERENCES:}

1. Polsky B, Kim AY, Chung RT. Human immunodeficiency virus and hepatitis B and C co -infection: pathogenic interactions, natural history and therapy. AIDS Clin Rev. 2000-2001; 263-306.

2. Chung RT. Hepatitis C and B viruses: the new opportunists in HIV infection. Top HIV Med.2006 Jun-Jul; 14(2):78-83. 


\section{ORIGINAL ARTICLE}

3. Alter MJ. Epidemiology of viral hepatitis and co-infection. J Hepatol 2006; 44 (Suppl 1): S 6-9.

4. P Ocama KC Opio M Kagimu E Seremba H Wabinga and R Colebunders. Hepatitis B virus and HIV infection among patients with primary hepatocellular carcinoma in Kampala, Uganda. Afr Health Sci. 2011 Aug; 11(Suppl 1): S20-S23.

5. Hoffmann CJ, Thio CL. Clinical implications of HIV and Hepatitis B co infection in Asia and Africa. Lancet Infect Dis 2007; 6: 402-9.

6. Gupta N, Kumar V, Kaur A. Seroprevalence of HIV, HBV, HCV and syphilis in voluntary blood donors. Indian J Med Sci 2004; 58:255-7.

7. Raza SA, Clifford GM, Franceschi S. World wide variation in the relative importance of hepatitis B and hepatitis C in hepatocellular carcinoma: a systematic review. Br J Cancer. 2007; 96: 11271134.

8. Bhatta CP, Thapa B, Rana BB. Seroprevalence of Hepatitis B in Kathmandu Medical College Teaching Hospital. Kathmandu Univ Med J (KUMJ) 2003; 1:113-6.

9. Hussain T, Kulshetra KK, Shikha V S HIV, HBV, HCV and syphilis co infections among patients attending the STD clinics of district hospitals in north India. Int. J .Of Infect. Dis 2006; 10:358363.

10. Bhattacharya S, Badrinath S, Hamide A, Sujatha S. Seroprevalence of hepatitis C virus in a hospital based general population in South India. Indian J Med Microbiol. 2003; 21:43-5.

11. Baheti R, Gehlot RS, Baheti R. Seroprevalence of Anti HCV Ab in healthy voluntary blood donors and in high risk individuals. J Indian Assoc Community Med. 2000; 1:230-2.

12. Mishra S, Chayani N, Sarangi G, Mallick B, Pati SB. Seroprevalence of anti HCV antibody in and around Cuttack, Orissa. Indian J Med Microbiol. 2002; 20:40-1.

13. Okonko IO, Anugeje KC and Adeniji FO. Syphilis and HIV HCV and HBsAg co-infecions among sexually active adults. Nature and Science 2012;10(1): 66-74.

14. Antala SK, Joshi TK. Seroprevalence of Hepatitis B, Hepatitis C and Syphilis in HIV positive cases at ICTC, Rajkot. Gujrat Medical Journal 2010; 65(1): 23-26.

\section{AUTHORS:}

1. Samatha P.

PARTICULARS OF CONTRIBUTORS:

1. Associate Professor, Department of Microbiology, Katuri Medical College.
NAME ADDRESS EMAIL ID OF THE CORRESPONDING AUTHOR:

Dr. Samatha $P$, No. 74-29-6; Lalbahudur Sastry Road, Ayappa Nagar, Vijayawada-7, Krishna District, Andhra Pradesh. E-mail: samathamicrobiology@gmail.com

Date of Submission: 30/09/2015. Date of Peer Review: 01/10/2015. Date of Acceptance: 12/10/2015. Date of Publishing: 20/10/2015. 